\title{
Potential Effect of Irisin and/or Moderate Intensity Exercise on Metabolic Homeostasis in Obesity in Male Albino Rats
}

\author{
ABEER A. ABOZEID, M.D. \\ The Department of Physiology, Faculty of Medicine, Tanta University, Egypt
}

\begin{abstract}
Background: Exercise may encourage myokines secretion such as irisin. Irisin is one of the myocytokines that is related to energy homeostasis and obesity.

Aim of Study: Study the effect of irisin and/or moderate intensity swimming exercise on metabolic homeostasis in high fat induced obesity in male albino rats.

Material and Methods: The present work will be carried out on 50 male albino rats, they were divided into 2 groups I: Control group 10 rats fed with normal diet and intraperitoneal injected with 150 s suline daily for 8 weeks II: Obese group 40 rats were fed with high fat diet they are subdivided into 4 subgroups 10 rats each IIa. Control obese IIb. Irisin treated Obese these rats are intraperitoneal injected with irisin in a dose of $100 \mathrm{ng} / \mathrm{ml}$ per day for 8 weeks IIc. Exercise treated Obese the exercise groups will swim for 30min a day, 5 days a week for 8 successive weeks IId. Irisin and exercise treated obese group rats will be treated as subgroup $\mathrm{b}$ and $\mathrm{c}$.
\end{abstract}

At the end of the experimental period, the following parameters were measured for all animals: Body Weight (BW), Body Mass Index (BMI), abdominal circumference. Blood samples were obtained to measure serum insulin, fasting blood glucose, calculate Homeostatic Model Assessment of Insulin Resistance (HOMA-IR) and, Homeostatic Model Assessment of Insulin Sensitivity (HOMA-S), measure serum Irisin, osteopontin, Total Cholesterol (TC), LDL cholesterol level, HDL cholesterol level, Triglycerides (TG), Free Fatty Acids (FFA), Nitrite/Nitrate and Malondialdehyde (MDA).

Results: Final BW in irisin and/or exercise animals are significantly decreased as compared to final BW of control obese group. Animal treated with Irisin and exercise shows insignificant change as compared to final $\mathrm{BW}$ in normal control group. BMI, abdominal circumpherence, serum insulin, fasting glucose, Homa IR, osteopontin, TC, LDL, TG, FFA, MDA are significantly increased in obese rats as compared to normal control, either Irisin injection or exercise results in significant decrease in all these parameters, when Irisin injection is combined with exercise it causes significant decrease when compared to control obese and insignifican difference with normal control group. As regard Irisin level, HOMA insulin sensitivity, HDL and Nitrite/Nitrate they are significantly decreased in obese rats as compared to normal

Correspondence to: Dr. Abeer A. Abo Zeid,

E-Mail: Abeer. Abozeid 2@yahoo.com control, either irisin injection or exercise results in significant increase in these parameters, if Irisin injection is combined with exercise it causes significant increase in these parameters reaching the normal control level.

Conclusion: Irisin and/or moderate intensity swimming exercise initiate a novel strategy for the treatment of obesity also the potential use of irisin as a predictive marker for insulin resistance has a therapeutic potential in obese rats.

Key Words: Obesity irisin-Exercise - Osteopontin.

\section{Introduction}

SKELETAL muscle cells secrete signaling cytokines peptides referred as myokines which act in an autocrine, paracrine, and endocrine fashion in response to exercise and contribute to the immediate and chronic benefits of exercise [1]. Regular physical activity is found to play a key role in reducing the risk of obesity by increasing energy expenditure, although the detailed mechanism of which remains unclear [2] Irisin is one of the mocytokines that is related to energy homeostasis and Obesity [3]. However the effect of exercise on serum irisin level showed the contradicting results. [4-6] The contradicting results of irisin responses induced by exercise might be resulted from the difference of exercise formula either it is resistant or aerobic exercise and the metabolic state.

The purpose of this study was to evaluate the association of swimming exercise that is typically considered an aerobic exercise and provides moderate resistance exercise and/or irisin treatment with serum irisin level and other obesity-associated parameters in high-fat-diet fed Wistar rats.

\section{Material and Methods}

\section{Animals:}

The present work was carried out on 50 male Wister rats ranging in weight between 150-200gm 
The rats were housed in isolated animal cages (five rats in each cage) in a standard animal laboratory room and had free access to water and food all over the period of work and were kept at room temperature. Animals were obtained from animal house of Tanta University and the experiment was approved by ethical committee of Faculty of Medicine, Tanta University (2019). This study was carried out in Physiology Department Tanta University (2019).

\section{Study design:}

Animals were divided into two groups:

Group I (Control group 10 rats): Fed with a Standard chow diet: $13.5 \%$ fat, $58 \%$ carbohydrate, $28.5 \%$ protein, and this represents $336 \mathrm{kcal} / 100 \mathrm{gm}$ till the end of the experiment [7].

Group II (obese group 40 rats): Rats of this group were fed with high fat diet $(50.10 \%$ fat mainly saturated; $33.60 \%$ carbohydrate; $16.30 \%$ protein; and this represents $493 \mathrm{kcal} / 100 \mathrm{~g}$ ) for 8 weeks [8] after the 8 weeks this group was subdivided into 4 equal Subgroups 10 rats each.

Subgroup IIa: Control obese group: Rats were treated by intraperitoneal injection of 150 Lsatine daily for 8 weeks.

Subgroup IIb: Irisin treated obese group: Rats were treated by intraperitoneal injection of 150 of prepared irisin solution $(100 \mathrm{ng} / \mathrm{ml})$ daily for 8 weeks, the solution was prepared by dissolving irisin powder in saline solution [9]

Subgroup IIc: Exercise treated obese group: Rats were treated by moderate intensity swimming exercise. It was performed without a load in a barrel filled with water at $33-35^{\circ} \mathrm{C}$ to a depth of $40-50 \mathrm{~cm}$, which allowed free swimming [10]. The duration of the first swimming exercise was limited to $15 \mathrm{~min}$ then increased by $5 \mathrm{~min}$ daily up to $30 \mathrm{~min}$. Rats in the exercise groups swam for 30min a day, 5 days a week for 8 successive weeks [11]

Subgroup IId: Irisin and exercise treated obese group: Rats were treated by intraperitoneal injection of 150 Loprepared irisin solution $(100 \mathrm{ng} / \mathrm{ml})$ daily for 8 weeks [9] in addition to exercise treatment as in subgroup IIc [11].

\section{Anthropometric measures:}

1- Body weight was measured at the start and the end of the experiment to evaluate the initial and final body weight using electronic scale.

2- BMI is calculated at the start (data not shown) and the end of the experimental period body mass index $(\mathrm{BMI})=$ Weight in grams/nose to anus length in $\mathrm{cm}$ [12].

3- Abdominal circumference were measured for all animals the biggest region of the rat's abdomen using soft ruler at the end of the experimental period.

\section{Samples collection and biochemical analysis:}

Blood samples were obtained from retro-orbital venous plexus 24 hours from the last exercise and animals allowed for fasting overnight. Serum was separated by centrifugation of blood at 3000rpm for 15 minutes and the separated sera were then stored in aliquots at $-30^{\circ} \mathrm{C}$ till used for estimation of the following parameters:

Fasting serum insulin by radioimmunoassay procedure using insulin ELISA kit [13] fasting serum glucose level by enzymatic colorimetric methods [14]. Homeostatic Model Assessment of Insulin Resistance (HOMA-IR) [15] Homeostatic model assessment of insulin sensitivity [15] are calculated, Serum Irisin [16], osteopontin [17] total cholesterol level [18], LDL cholesterol level [19], HDL cholesterol level was measured according to method of Grove [20]. Triglycerides level was measured by GPO enzymatic method [21], free fatty acids [22], Nitrite/Nitrate level [23]. Malondialdehyde (MDA) [24] levels were measured.

\section{Statistical analysis:}

All values were expressed as mean \pm Standard Deviation (SD). Data were statistically analyzed using one way ANOVA for multiple group comparisons, followed by scheffe (F) for comparison between individual group. Significance was set at $(p \leq 0.05)$.

\section{Results}

As shown in (Table 1) final BW in irisin ttt or exercise ttt animals are significantly decreased as compared to final BW of control obese group. Animal treated with Irisin and exercise show significant decrease in final $\mathrm{BW}$ compared to control obese rats, also they show insignificant change compared to either initial or final BW in normal control group, as regard BMI and Abdominal circumference both are significantly increased in control obese rats as compared to normal control group, either Irisin injection or exercise results in significant decrease in them as compared to control obese group, when Irisin injection is combined with exercise it causes significant decrease and improvement in these parameters reaching the normal control level. 
Table (2) showed that osteopontin and Malondialdehyde are significantly increased in control obese rats as compared to normal control group, either Irisin injection or exercise results in significant decrease in all these parameters as compared to control obese group, when Irisin injection is combined with exercise it causes significant decrease and improvement in these parameters reaching the normal control level. As regard irisin level and nitrite/nitrate level they are significantly decreased in control obese rats as compared to normal control either irisin injection or exercise results in significant increase these parameters as compared to control obese group, if Irisin injection is combined with exercise it causes significant increase in these parameters reaching the normal control level.
Table (3) showed significant increase in Serum insulin, fasting glucose, Homa IR, total cholesterol, LDL, Triglyceride, FFA, in obese control rats as compared to normal control group either irisin injection or exercise results in significant decrease these parameters as compared to control obese group, if Irisin injection is combined with exercise it causes significant decrease in these parameters reaching the normal control level. On the other hand it showed significant decrease in HOMA-IS and HDL in obese control rats as compared to normal control group either irisin injection or exercise results in significant increase these parameters as compared to control obese group, if Irisin injection is combined with exercise it causes significant decrease in these parameters reaching the normal control level.

Table (1A): Initial and final body weight in all groups studied (mean \pm SD).

\begin{tabular}{|c|c|c|c|c|c|c|c|c|c|c|}
\hline \multirow[b]{3}{*}{ Parameters } & \multirow{2}{*}{\multicolumn{2}{|c|}{ Normal control }} & \multicolumn{8}{|c|}{ Obese } \\
\hline & & & \multicolumn{2}{|c|}{ Control } & \multicolumn{2}{|c|}{ Irisin $\mathrm{ttt}$} & \multicolumn{2}{|c|}{ Exercise $\mathrm{ttt}$} & \multicolumn{2}{|c|}{ Irisin \& exercise $\mathrm{ttt}^{\mathrm{s}}$} \\
\hline & Initial & Final & Initial & Final & Initial & Final & Initial & Final & Initial & Final \\
\hline Body weight (gm) & $\begin{array}{l}191 \pm \\
24.3\end{array}$ & $\begin{array}{l}274.7 \mathbf{a} \pm \\
38.0\end{array}$ & $\begin{array}{l}288 \mathbf{a} \pm \\
30.3\end{array}$ & $\begin{array}{l}437.4 \text { bc } \pm \\
43.2\end{array}$ & $\begin{array}{l}288 \mathbf{a} \pm \\
30.3\end{array}$ & $\begin{array}{l}310.5 \text { bde } \pm \\
29.8\end{array}$ & $\begin{array}{l}288 \mathbf{a} \pm \\
30.3\end{array}$ & $\begin{array}{l}315.7 \text { bdg } \pm \\
25.1\end{array}$ & $\begin{array}{l}288 \mathbf{a} \pm \\
30.3\end{array}$ & $\begin{array}{l}269.9 \text { dfh } \\
\pm 41.5\end{array}$ \\
\hline $\begin{array}{l}p \text {-value }>0.05 \text {. } \\
\text { a: Sig vs. initial norm } \\
\text { b: Sig vs. final norma } \\
\text { c: Sign vs. initial con } \\
\text { d: Sign vs. final contr }\end{array}$ & $\begin{array}{l}1 \text { control. } \\
\text { control. } \\
\text { ol obese. } \\
\text { l obese. }\end{array}$ & & & & $\begin{array}{l}\text { e: Sig vs } \\
\text { f: Sig vs. } \\
\text { g: Sig vs } \\
\text { h: Sig vs }\end{array}$ & $\begin{array}{l}\text { initial irisin tr } \\
\text { inal irisin trea } \\
\text { initial exercis } \\
\text { final exercise }\end{array}$ & $\begin{array}{l}\text { ted obes } \\
\text { ed obese. } \\
\text { treated o } \\
\text { eated ob }\end{array}$ & & & \\
\hline
\end{tabular}

Table (1B): BMI, abdominal circumference, in all studied groups (mean values $\pm \mathrm{SD}$ ).

\begin{tabular}{|c|c|c|c|c|c|}
\hline \multirow[b]{2}{*}{ Parameters } & \multirow{2}{*}{$\begin{array}{c}\text { Normal } \\
\text { al control }\end{array}$} & \multicolumn{4}{|c|}{ Obese } \\
\hline & & Control & Irisin $\mathrm{ttt}$ & Exercise $\mathrm{ttt}$ & Irisin \& exercise $\mathrm{ttt}$ \\
\hline $\mathrm{BMI}\left(\mathrm{gm} / \mathrm{cm}^{2}\right)$ & $0.596 \pm 0.106$ & $0.950 \mathbf{a} \pm 0.140$ & $0.667 \mathbf{b} \pm 0.141$ & $0.681 \mathbf{b} \pm 0.142$ & $0.579 \mathbf{b} \pm 0.141$ \\
\hline Abdominal circumference $(\mathrm{cm})$ & $14.47 \pm 1.428$ & $21.73 \mathrm{a} \pm 2.428$ & $16.91^{\mathbf{a}^{\prime} \mathbf{b} \pm 1.226}$ & 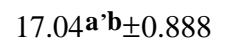 & $14.53 \mathbf{b , c , d} \pm^{1} \cdot{ }^{21}$ \\
\hline
\end{tabular}

$p$-value $>0.05$

a: Sig vs. normal control

b: Sig vs. control obese.

c: Sign vs. Irisin treated obese.

d: Sign vs. exercise ttt.

Table (2): Serum irisin, osteopontin, Nitrite/Nitrate, Malondialdehyde in all studied groups (mean values \pm SD).

\begin{tabular}{|c|c|c|c|c|c|}
\hline \multirow{2}{*}{ Parameters } & \multirow{2}{*}{ Normal control } & \multicolumn{4}{|c|}{ Obese } \\
\hline & & Control & Irisin $\mathrm{ttt}$ & Exercise $\mathrm{ttt}$ & Irisin \& exercise $\mathrm{ttt}$ \\
\hline Serum irisin $(\mathrm{ng} / \mathrm{ml})$ & $37.9 \pm 3.089$ & $28.83 \mathbf{a} \pm 3.418$ & $69.71^{\mathbf{a}^{\prime}} \mathbf{b}_{ \pm 4.403}$ & $72.96^{\mathbf{a}^{\prime} \mathbf{b} \pm 4.684}$ & 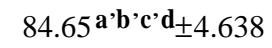 \\
\hline Serum osteopontin (ng/ml) & $36 \pm 3.4$ & $76.5 \mathbf{a} \pm 4.4$ & $63.7^{\mathbf{a}^{\prime} \mathbf{b} \pm 5.9}$ & $66.7^{\mathbf{a}^{\prime} \mathbf{b} \pm 5.5}$ & $38.1^{\mathbf{b}^{\prime} \mathbf{c}^{\prime} \mathbf{d} \pm 3.8}$ \\
\hline Nitrite/Nitrate ( mallu) & $15.90 \pm 1.921$ & $9.35 \mathrm{a} \pm 1.23$ & $11.53 \mathbf{a}^{\mathbf{a}} \mathbf{b} \pm 1.56$ & $11.12^{\mathbf{a}, \mathbf{b} \pm 1.32}$ & $15.42 \mathbf{b}, \mathbf{c}, \mathbf{d} \pm 1.77$ \\
\hline Malondialdehyde ( $\mathrm{mol} / \mathrm{L})$ & $1.36 \pm 0.20$ & $2.74 \mathbf{a} \pm 0.35$ & $1.9 \mathbf{a}^{\mathbf{a}} \pm 0.09$ & $1.94^{\prime} \mathbf{a}^{\prime} \mathbf{b} \pm 0.13$ & $1.43^{\mathbf{b}, \mathbf{c}, \mathbf{d}_{ \pm 0.17}}$ \\
\hline
\end{tabular}


Table (3): Serum fasting glucose, insulin. HOMA-IR, (HOMA-S) in all studied groups (mean values \pm SD).

\begin{tabular}{|c|c|c|c|c|c|}
\hline \multirow{2}{*}{ Parameters } & \multirow{2}{*}{ Normal control } & \multicolumn{4}{|c|}{ Obese } \\
\hline & & Control & Irisin $\mathrm{ttt}$ & Exercise $t t t$ & Irisin \& exercise $\mathrm{ttt}$ \\
\hline Serum fasting glucose $(\mathrm{mg} / \mathrm{dl})$ & $88.41 \pm 8.19$ & $148.7 \mathbf{a} \pm 10.17$ & $106.49 \mathbf{a}^{\prime} \mathbf{b} \pm 14.57$ & $110.3 \mathbf{a}^{\mathbf{a}} \mathbf{b} \pm 12.33$ & $83.900^{\mathbf{b}} \mathbf{c}^{\prime} \mathbf{d} \pm 8.408$ \\
\hline Serum insulin ( JUml) & $12.24 \pm 1.788$ & $18.66 \mathrm{a} \pm 2.095$ & $13.98 \mathbf{a}^{\mathbf{a}} \mathbf{b} \pm 1.24$ & $14.06^{\mathbf{a}^{\prime} \mathbf{b} \pm 1.362}$ & $12.40^{\mathbf{b}^{\prime} \mathbf{c}^{\prime} \mathbf{d}_{ \pm} 1.902}$ \\
\hline HOMA-IR & $2.65 \pm 0.287$ & $6.84 \mathrm{a} \pm 0.861$ & $3.77^{\mathbf{a}} \mathbf{a}_{ \pm 0.384}$ & $3.79^{\mathbf{a}^{\prime} \mathbf{b} \pm 0.309}$ & $2.55^{b^{\prime}} \mathbf{c}^{\prime} d_{ \pm 0.365}$ \\
\hline (HOMA-S) & $0.329 \pm 0.005$ & $0.290 \mathrm{a} \pm 0.004$ & $0.315^{\mathbf{a}^{\prime} \mathbf{b} \pm 0.007}$ & $0.313^{\mathbf{a}^{\prime} \mathbf{b} \pm 0.003}$ & $0.331^{\mathbf{b}} \mathbf{c}^{\prime} \mathbf{d}_{ \pm 0.008}$ \\
\hline
\end{tabular}

a: Sig vs. normal control.

c: Sign vs. Irisin treated obese.

b: Sig vs. control obese.

d: Sign vs. exercise ttt.

Table (4): Lipid profile in all studied groups (mean values \pm SD).

\begin{tabular}{|c|c|c|c|c|c|}
\hline \multirow{2}{*}{ Parameters } & \multirow{2}{*}{ Normal control } & \multicolumn{4}{|c|}{ Obese } \\
\hline & & Control & Irisin $\mathrm{ttt}$ & Exercise $\mathrm{ttt}$ & Irisin \& exercise $\mathrm{ttt}$ \\
\hline Serum total cholesterol (mg/dl) & $104.2 \pm 7.192$ & $163.7 \mathbf{a} \pm 46.54$ & $122.9 \mathrm{a}, \mathrm{b} \pm 9.43$ & $127.4 \mathbf{a}^{\prime} \mathbf{b} \pm 10.79$ & $102.4 \mathbf{b}^{\prime} \mathbf{c}^{\prime} \mathbf{d} \pm 16.87$ \\
\hline Serum LDL cholesterol (mg/dl) & $49.15 \pm 4.51$ & $73.97 \mathbf{a} \pm 4.84$ & $56.02^{\mathbf{a}^{\prime} \mathbf{b} \pm 5.35}$ & $54.30^{\mathbf{a}} \mathbf{b} \pm 4.90$ & $48.01 \mathbf{b}^{\prime} \mathbf{c}^{\prime} \mathbf{d} \pm 4.90$ \\
\hline Serum HDL cholesterol (mg/dl) & $41.12 \pm 4.09$ & $24.03 \mathrm{a} \pm 4.16$ & $34.93 \mathbf{a}^{\mathbf{a}} \mathbf{b} \pm 4.20$ & $36.45^{\mathbf{a}^{\prime} \mathbf{b} \pm 4.15}$ & $41.70^{\mathbf{b}} \mathbf{c}^{\prime} \mathbf{d} \pm 3.94$ \\
\hline Serum triglycerides (mg/dl) & $137.5 \pm 7.587$ & $176.7 \mathbf{a} \pm 9.851$ & $147.3 \mathbf{a}^{\prime} \mathbf{b} \pm 9.891$ & $145.3 \mathbf{a}^{\prime} \mathbf{b} \pm 7.377$ & $134.3 \mathbf{b}, \mathbf{c}, \mathbf{d} \pm 7.704$ \\
\hline Serum free fatty acids $(\mathrm{mmol} / \mathrm{ml})$ & $86.3 \pm 6.56$ & $189.9 \mathrm{a} \pm 10.53$ & $157 \mathbf{a}^{\mathbf{a}} \mathbf{b} \pm 10.49$ & $163.2^{\mathbf{a}} \mathbf{b} \pm 14.97$ & $87.5 b^{\prime} \mathbf{c}^{\prime} \mathbf{d} \pm 9.7$ \\
\hline
\end{tabular}

\section{Discussion}

It is evident from the results of the present work the beneficial effect of either irisin or exercise on body weight as it significantly decreased final BW in irisin ttt or exercise ttt animal. In addition, animal treated with both Irisin \& exercise show significant decrease in BW compared to final BW in control obese animals, irisin ttt group and exercise $t t$ group and with insignificant difference from final BW of normal control. This indicate that combination of irisin and exercise treatment are more potent in reducing body weight in obese animal.

Body weight, BMI,abdominal circumference are significantly decreased due to conversion of white adipocytes to brown one by irisin leads to increase energy expenditure and thermogenesis with decrease in these anthropometric parameters [25], negative association between circulating irisin with body weight, BMI and abdominal circumference has been previously reported [26]

Results of present work denote that irisin is significantly decreased in obese rats Irisin is secreted from skeletal muscle into circulation by proteolytical cleavage of Fibronectin type III domain-containing protein5 (FNDC5) [27], the precursor of irisin. In obesity, FNDC5 expression, and consequently secretion of irisin from adipocytes is decreased [26]. This results are in accordance with previous results that show reduction of irisin in obese Chinese adults [28]. Lower levels of circulating irisin in obese group could be explained by impaired peroxisome proliferator activated receptor-gamma coactivator 1 alpha (PGC-1a) expression and functions in the muscle and adipose tissue PGC-1a is a master regulator of irisin secretion. Moreno-Navarrete et al., reported a decreased circulating irisin concentration and FNDC5 gene expression in adipose tissue and muscle from obese with a subsequent reduction in mitochondrial biogenesis and thus depression of irisin-the PGC- $1 \alpha$ dependent myokines. [29] But the significant increase in glucose, insulin, HOMA IR in obese rats observed in this study could be a cause of decrease PGC- $1 \alpha$ activity and decrease of irisin [30]

Kurdiova et al., suggest that chronic hyperglycemia and hyperlipidemia are possible causes for decreased FNDC5 gene expression [31]. The low irisin concentrations in obese could be also explained by hyperlipidemia but the Potential associations between irisin concentration and lipid profile are poorly understood [32]. Gouni-Berthold identified higher probabilities of raised lipid levels in subjects with low irisin concentrations as in obese with inverse associations between irisin concentrations and total, LDL cholesterol as well as triglycerides [33].

Additional decrease in irisin secretion from adipose tissue as a result of the inflammatory processes and oxidative stress observed in obesity 
cannot be excluded [34]. Obesity is characterized by low-grade chronic inflammation and it induces elevated oxidative stress. Increased production of ROS impairs cellular structures together with decreased antioxidant defense system [35].

Malondialdehyde (MDA) a marker of oxidative stress was significantly increased in control obese animals this reflects in vivo oxidative damage to lipids and increased plasma lipid peroxidation.

It is clear that the level of osteopontin is significantly increase in obese rats Osteopontin, is an extracellular matrix protein may play a key role in linking obesity to the development of insulin resistance by promoting inflammation and the accumulation of macrophages in adipose tissue with subsequent decrease in irisin in these animals [36].

Nitrite/Nitrate are significantly reduced in obese rats. Piva et al., reported negative associations between nitrite/nitrate levels and obesity which were mediated by inflammation [37]. Impaired NO metabolism, especially reduced NO production and bioavailability, has been recognized as a risk factor for development of obesity [38] .

Physical exercise increases endogenous irisin, reduced adiposity and improved energy balance and subclinical inflammation [39]. It is evident from our results that after exercise irisin concentrations increase significantly. Varela-Rodríguez et al., correlated the relation of Irisin mRNA levels in muscle tissue and irisin levels in the blood plasma [40].

Aerobic exercise increases serum irisin level and prompt uncoupling protein 1 (UCP1) mRNA expression in inguinal white adipose tissue, on the other hand injection of an anti-irisin antibody proceeding to exercise prevent this increase in UCP1. This suggests that irisin is an important stimulus to white adipose tissue to increase UCP1 expression after exercise [27]. However Fain et al., observed that serum irisin levels increase only in familial hypercholesterolemic animals not in normal metabolic states after aerobic exercise [41]. Huh et al., found that serum irisin increases after 30 minutes of exercise [42]. Similarly, Kraemer et al., found increase in serum irisin levels in the first 54 minutes of treadmill [43]. Sharma et al., reported a positive feedback loop whereby increased circulating irisin increases PGC 1 á levels, which in turn induces further irisin secretion. PGC1á is in fact the master regulator capable of increasing UCP1 protein in brown adipose tissue [44].
In the present study, 8 weeks of moderate intensity swimming exercise or exogenous administration of irisin to obese rats, significantly improved all metabolic profile, oxidative and inflammatory parameters as compared to control obese group, on the other hand all parameters studied are returned to normal control level in group treated both irisin and exercise. Irisin reduces oxidative stress as proved by significant decrease in MDA, it has been previously reported that Irisin prevent oxidative stress in the liver through the inhibition of protein arginine methyltransferase-3 [45] Wang et al., established that Irisin treatment reduces I/R-induced oxidative stress as it increases SOD activity [46].

Furthermore, irisin significantly increases NO level, it has been previously reported that swimming exercise increases eNOS expression at the protein level [47].

Also irisin itself increased NO production and phosphorylation of endothelial nitric oxide synthase (eNOS) in endothelial cells [48]

Combination of irisin administration and/or induction of endogenous irisin release by exercise reduce fasting blood glucose and increase insulin sensitivity. This improvement in glucose and lipid profile was achieved by increase glucose uptake combined with reduce gluconeogenesis in the liver [49]. Exercise induced overexpression of Fndc5 in obese animals reduced hyperglycemia and hyperinsulinemia [50]

Irisin prevent glucose/lipid metabolic dearangement, improve insulin resistance and increase energy expenditure via enhance lipolysis and uncoupling of oxidative phosphorylation [51].

Irisin is insulin-regeneration hormone and can accelerate the generation of beta cell it has an antiapoptotic action on pancreatic beta cells stimulate their proliferation and insulin biosynthesis and secretion [52] it has a potent antioxidant, antiinflammatory activities especially under condition of exercise [53].

\section{Conclusion:}

Swimming exercise that represent aerobic and resistant exercise in the same time increase irisin secretion in abnormal metabolic state. Irisin either endogenous or exogenous initiate a novel strategy for the treatment of obesity and its complications even in absence of caloric restriction through ameliorating oxidative stress, increasing NO production reducing osteopontin that is new indicator for insulin resistance associated with metabolic syndrome. 


\section{References}

1- IRVING B.A., STILL C.D. and ARGYROPOULOS G.: Does IRISIN Have BRITE Future as a Therapeutic Agent in Humans?. Curr. Obes. Rep., 3: 235-41, 2014.

2- YUN L.U., HONGWEI L.I., SHI-WEI SHEN, ZHENHAI SHEN, MING X.U., et al.: Swimming exercise increases serum irisin level and reduces body fat mass in high-fat-diet fed Wistar rat Lipids in Health and Disease. 5: 93-7, 2016.

3- PEDERSEN B.K. and FEBBRAIO M.A.: Muscles, exercise and obesity: Skeletal muscle as a secretory organ Nature Reviews Endocrinology, 8: 4579-65, 2012.

4- NORHEIM F., LANGLEITE T.M., HJORTH M., et al.: "The effects of acute and chronic exercise on PGC- $1 \alpha$, irisin and browning of subcutaneous adipose tissue in humans," FEBS Journal, 281 (3): 739-49, 2014.

5- HECKSTEDEN A., WEGMANN M., STEFFEN A., et al.: "Irisin and exercise training in humans-results from a randomized controlled training trial," BMC Medicine, 11 (1): 235, 2013.

6- KIM H.J., LEE H.J., SO B., SON J.S., YOON D. and SONG W.: "Effect of aerobic training and resistance training on circulating irisin level and their association with change of body composition in overweight/obese adults: A pilot study," Physiological Research, 65 (2): 271, 2016.

7- SAIHAN BORGHJID and RICHARD DAVID FEINMAN: Response of C57B1/6 mice to a carbohydrate-free diet Nutr. Metab. (Lond), 9: 69, 2012.

8- HOU N., HAN F., WANG M., HUANG N., ZHAO J., et al.: Perirenal fat associated with microalbuminuria in obese rats. Int. Urol. Nephrol., 46: 839-45, 2014.

9- BASIL O. SALEH, MAYSAA J. MAJEED and GHASSAN M. OREABY: Irisin impact as a medication that ameliorate and hinder the development of insulin resistance associated disorders without regular exercise (experimental study) Journal of Dental and Medical Sciences 13, Issue 9: 28-35, 2014.

10- LI H., SHEN Z., LU Y., LIN F., WU Y. and JIANG Z. Muscle NT-3 levels increased by exercise training contribute to the improvement in caudal nerve conduction velocity in diabetic rats. Mol. Med. Rep., (6): 69-74, 2012.

11- GOBATTO C.A., De MELLO M.A., SIBUYA C.Y., De AZEVEDO J.R., DOS SANTOS L.A. and KOKUBUN E.: Maximal lactate steady state in rats submitted to swimming exercise Comparative Biochemistry and Physiology Part A: Molecular \& Integrative Physiology, 130: 21-7, 2001.

12- NOVELLI E.L., DINIZ Y.S., GALHARDI C.M., EBAID G.M., RODRIGUES H.G., et al.: Anthropometrical parameters and markers of obesity in rats. Lab. Anim., 41: 111-9, 2007.

13- KAO P.C., TAYLOR R.L. and SERVICE F.J.: Proinsulin by Immunochemiluminometric Assay for the Diagnosis of Insulinoma. Jorunal of Clin. Endocrinol. Metab., 78 (5): 1048-105, 1994.

14- TIETZ N.W.: Determination of blood glucose. Text book of clinical chemistry WB Saunders, Philadelphia, 796, 1986.
15- MATTHEWS D.R., HOSKER J.P., RUDENSKI A.S., NAYLOR B.A., TREACHER D.F. and TURNER R.C.: Homeostasis model assessment: Insulin resistance and beta-cell function from fasting plasma glucose and insulin concentrations in man. Diabetologia, 28: 412-19, 1985.

16- JEDRYCHOWSKI M.P., WRANN C.D., PAULO J.A., GERBER K.K., SZPYT J., ROBINSON M.M. et al.: Detection and Quantitation of Circulating Human Irisin by Tandem Mass Spectrometry. Cell. Metab., 6; 22 (4): 734-40, 2015.

17- AL-ZOUBI S., WASSOUF A. and ZETOUNE A.B.: Measuring levels of osteopontin as potential biomarker for hepatocellular carcinoma in Syrian patients. Gastroenterol. Hepatol. Bed. Bench., 10 (2): 97-101, 2017.

18- TIETZ N.W.: Fundamentals of Clinical Chemistry WB Saunders. Philadelphia, 322-36, 1976.

19- ASSMANN G., JABS H.U., KOHNERT U., NOLTE W and SCHRIEWER H.: LDL-cholesterol determination in blood serum following precipitation of LDL with polyvinylsulfate Clinica Chimica Acta 140, Issue 1, 27: 77-83, 1984.

20- GROVE T.H.: Effect of reagent $\mathrm{pH}$ on determination of high-density lipoprotein cholesterol by precipitation with sodium phosphotungstate-magnesium. Clin. Chem., 25 (4): 560-4, 1979.

21- MCGOWAN M.W., ARTISS J.D., STRANDBERGH D.R and ZAK B.: A peroxidase-coupled method for the colorimetric determination of serum triglycerides. Clin. Chem., 29 (3): 538-42, 1983.

22- ANTONIS A.: Semiautomated method for the colorimetric determination of plasma free fatty acids. Journal of Lipid Research, 6: 307-12, 1965.

23- MONTGOMERY H.A. and DYMOCK J.F.: Colorimetric determination of nitric oxide. In. Analyst., 86-414, 1961.

24- OHKAWA H., OHISHI N. and YAGI K.: Assay for lipid peroxides in animal tissues by thiobarbituric acid reaction. Anal. Biochem., 95 (2): 351-8, 1979.

25- YUAN ZHANG, RUI L.I., YAN MENG, SHIWU L.I. WILLIAM DONELAN, YAN ZHAO2, et al.: Irisin Stimulates Browning of White Adipocytes Through MitogenActivated Protein Kinase p38 MAP Kinase and ERK MAP Kinase Signaling Diabetes Feb., 63 (2): 514-525f, 2014.

26- ELIZONDO-MONTEMAYOR L., MENDOZA-LARA G., GUTIERREZ-DELBOSQUE G., PESCHARDFRANCO M., NIEBLAS B., et al.: Relationship of Circulating Irisin with Body Composition, Physical Activity, and Cardiovascular and Metabolic Disorders in the Pediatric Population. Int. J. Mol. Sci. Nov., 23: 19 (12), 2018.

27- BOSTRÖM P., WU J., JEDRYCHOWSKI M.P., KORDE A., YE L., et al.: A PGC1-[agr]-dependent myokine that drives brown-fat-like development of white fat and thermogenesis. Nature., 481 (7382): 463-8, 2012.

28- YAN B., SHI X., ZHANG H., PAN L., MA Z., et al.: Association of serum irisin with metabolic syndrome in obese Chinese adults. PLoS. One., 9 (4): e94235, 2014.

29- MORENO-NAVARRETE J.M., ORTEGA F., SERRANO M., GUERRA E., PARDO G., et al.: Irisin is expressed and produced by human muscle and adipose tissue in 
association with obesity and insulin resistance. J. Clin. Endocrinol. Metab., 98 (4): 769-78, 2013.

30- ADRIAN M., GONZALEZ-GIL, MARIANA PESCHARD-FRANCO, ELENA C., CASTILLO, GUSTAVO GUTIERREZ-DELBOSQUE, VICTOR TREVIÑO, et al.: Myokine-adipokine cross-talk: Potential mechanisms for the association between plasma irisin and adipokines and cardiometabolic risk factors in Mexican children with obesity and the metabolic syndrome Diabetology \& Metabolic Syndromevolume 11, Article number, 63, 2019.

31- KURDIOVA T., BALAZ M., VICIAN M., MADEROVA D., VLCEK M., et al.: Effects of obesity, diabetes and exercise on Fndc5 gene expression and irisin release in human skeletal muscle and adipose tissue: In vivo and in vitro studies. J. Physiol., 1; 592 (5): 1091-107, 2014.

32- OELMANN S., NAUCK M., VÖLZKE H., BAHLS M. and FRIEDRICH N.: Circulating Irisin Concentrations Are Associated with a Favourable Lipid Profile in the General Population PLoS. One. Apr. 29; 11 (4): e0154319, 2016.

33-GOUNI-BERTHOLD I., BERTHOLD H.K., HUH J.Y., BERMAN R., SPENRATH N., et al.: Effects of lipidlowering drugs on irisin in human subjects in vivo and in human skeletal muscle cells ex vivo. PLoS. One. Sep., 2; 8 (9): e72858, 2013.

34- ELIZONDO-MONTEMAYOR, CHRISTIAN SILVAPLATAS, ALEJANDRO TORRES-QUINTANILLA, CARLOS RODRÍGUEZ-LÓPEZ, GUILLERMO U., RUIZ-ESPARZA, et al.: Association of irisin plasma levels with Anthropometric Parameters in Children with Underweight, Normal Weight, Overweight, and Obesity Biomed Res. Int., 2017; 2628968, 2017.

35- BHALE D.V., PATIL D.S. and MAHAT R.K'.: Study of Malondialdehyde (MDA) As a Marker of Oxidative Stress in Obese Male Individuals. International Journal of Recent Trends in Science And Technology Volume 10, Issue 1, 51-2, 2014.

36- KAHLES F., FINDEISEN H.M., BRUEMMER D. and OSTEOPONTIN: A novel regulator at the cross roads of inflammation, obesity and diabetes Mol. Metab., 22; 3 (4): 384-93, 2014.

37- PIVA S.J., TATSCH E., De CARVALHO J.A.M., et al.: Assessment of inflammatory and oxidative biomarkers in obesity and their associations with body mass index. Inflammation, 36: 226-31, 2013.

38- KNOTT A B. and ELLA BOSSY-WETZEL: Impact of nitric oxide on metabolism in health and age-related disease Diabetes. Obes. Metab., 12 (02): 126-33, 2010.

39- GHULAM NABI, NAVEED AHMAD, SARDAR ALI and SULTAN AHMAD: Irisin: A Possibly New Therapeutic Target for Obesity and Diabetes Mellitus. World Journal of Zoology 10 (3): 205-10, 2015.

40- VARELA-RODRÍGUEZ B.M., PENA-BELLO L., JUIZVALIÑA P., VIDAL-BRETAL B. and CORDIDO F.: FNDC5 expression and circulating irisin levels are modified by diet and hormonal conditions in hypothalamus, adipose tissue and muscle Sci. Rep., 6: 29898, 2016.

41- FAIN J.N., COMPANY J.M., BOOTH F.W., LAUGHLIN M.H., PADILLA J., et al.: Exercise training does not increase muscle FNDC5 protein or mRNA expression in pigs. Metabolism, 62: 1503-11, 2013.
42- HUH J.Y., PANAGIOTOU G., MOUGIOS V., BRINKOETTER M., VAMVINI M.T., et al.: Fndc5 and irisin in humans: I. Predictors of circulating concentrations in serum and plasma and ii. Mrna expression and circulating concentrations in response to weight loss and exercise. Metabolism: Clinical and experimental, 61: 1725-38, 2012.

43- KRAEMER R.R., SHOCKETT P., WEBB N.D., SHAH U. and CASTRACANE V.D.: A transient elevated irisinblood concentration in response to prolonged,moderate aerobic exercise in young men and women. Hormone and Metabolic Research, 46: 150-4, 2014.

44- SHARMA B.K., PATIL M. and SATYANARAYANA A.: Negative Regulators of Brown Adipose Tissue (BAT)Mediated Thermogenesis. Journal of Cell Physiology, 229: 1901-7, 2014.

45- PARK M.J., KIM D.I., CHOI J.H., HEO Y.R. and PARK S.H.: New role of irisin in hepatocytes: The protective effect of hepatic steatosis in vitro. Cell. Signal., 27 (9): 1831-9, 2015.

46- WANG Z., CHEN K., HAN Y., ZHU H. and ZHOU X. Irisin Protects Heart Against Ischemia-Reperfusion Injury Through a SOD2-Dependent Mitochondria Mechanism. J. Cardiovasc. Pharmacol. Dec., 72 (6): 259-69, 2018.

47- PELLEGRIN M., MIGUET-ALFONSI C., BERTHELOT A., MAZZOLAI L. and LAURANT P.: Long-term swimming exercise does not modulate the Akt-dependent endothelial nitric oxide synthase phosphorylation in healthy mice. Can. J. Physiol. Pharmacol., 89: 72-6 10.1139/Y10-107, 2011

48- JINJUAN F.U., YU HAN, JIALIANG WANG, YUKAI LIU, SHUO ZHENG, et al.: Irisin Lowers Blood Pressure by Improvement of Endothelial Dysfunction via AMPK Akt-eNOS-NO Pathway in the Spontaneously Hypertensive Rat. L. J. Am. Heart. Assoc. Nov., 5 (11): e003433, 2016.

49- PÓSA A., SZABÓ R., KUPAI K., CSONKA A., SZALAI Z., VESZELKA M., et al.: Exercise training and calorie restriction influence the metabolic parameters in ovariectomized female rats. Oxid. Med. Cell. Longev., 2015: 787063, 2015

50- BONFANTE I.L., CHACON-MIKAHIL M.P., BRUNELLI D.T., GÁSPARI A.F., DUFT R.G., et al.: Combined training, FNDC5/irisin levels and metabolic markers in obese men: A randomised controlled trial- Eur. J. Sport. Sci. Jun., 17 (5): 629-37, 2017.

51- CHEN J.Q., HUANG Y.Y., GUSDON A.M. and QU S.: Irisin: A new molecular marker and target in metabolic disorder. Lipids in Health and Disease, 14 (2): 1476-511, 2015.

52- LIU S., DU F., LI X., WANG M., DUAN R., ZHANG J., et al.: Effects and underlying mechanisms of irisin on the proliferation and apoptosis of pancreatic P cells. PLoS One, 12 (4): e0175498, 2017.

53- MAZUR-BIALY A., KAMILA KOZ'LOWSKA and EWA POCHEC: Myokine irisin-induced protection against oxidative stress in vitro. Involvement of heme oxygenase1 and antioxidazing enzymes superoxide dismutase- 2 and glutathione peroxidase. Journal of physiology and pharmacology: An official journal of the Polish Physiological Society, 69 (1): 117, 2018. 


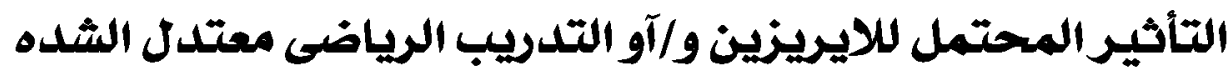

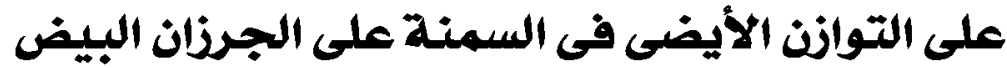

\author{
الخلفية: التمرين قد يشجع إفراز الميوكين مثل الاريزين وهو مرتبط بتوازن الطاقة والسمنة.
}

الهدف: دراسة تأثير الايريزين و/آو ممارسة السباحة ذات الكثافة المعتدلة على التوانن الأيضي في العمنة عالية الدهون المستحثة فى الفئران الذكور البيضـاء

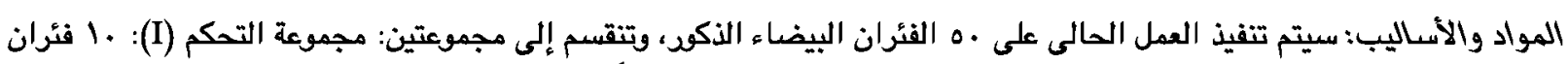

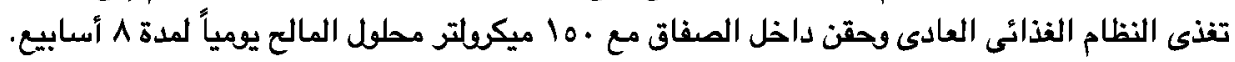

ثانيا: مجموعة البدناء (II) تم تفذية ـ ع من الفئران نظام غذائى عالى الدسم انها تنقسم إلى ع مجموعات فرعية ـا من الفئران فى كل

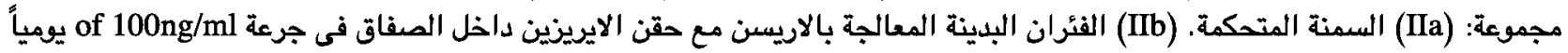

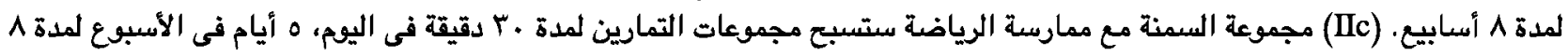

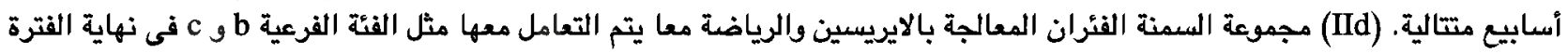

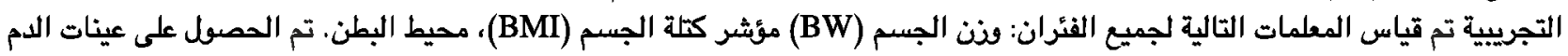

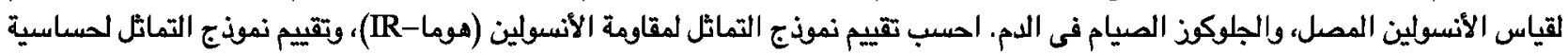

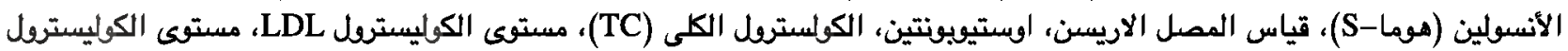

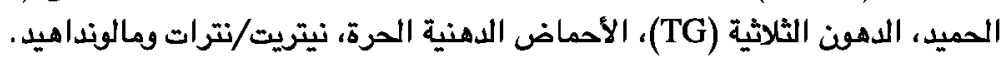

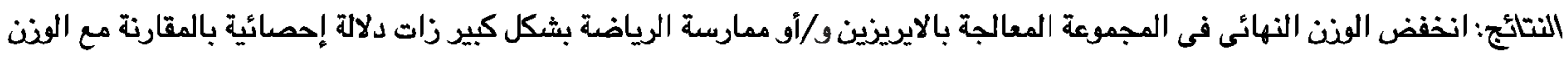

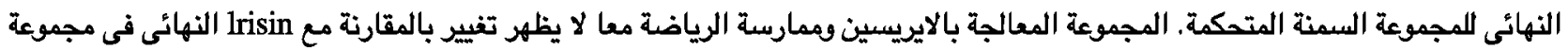

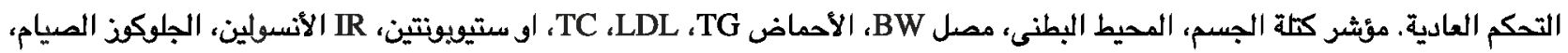

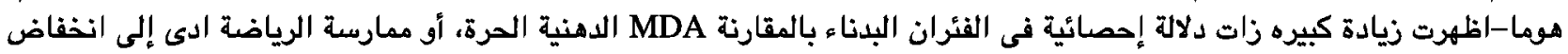

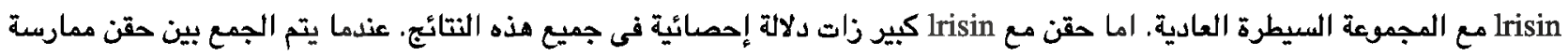
الرياضة انه يسبب انخفاضا كبير زات دلالة إحصائية بالمقارنة مع مجموعة السمنة المسيطرة والفرق ليس له دلالة إحصائية مع مجموعة التحكم

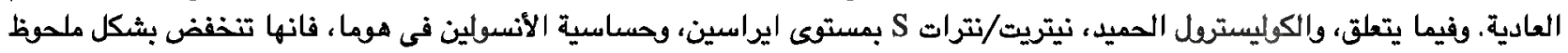

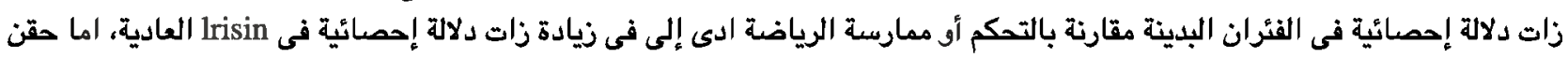

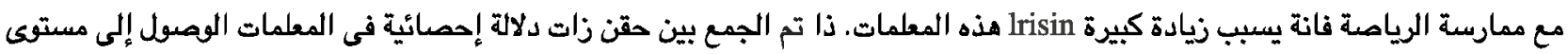
التمكم العادى.

الاستتاج: و/أو مماربسة السباحة كثافة معتدلة بلءء استراتيجية جديلة لعلاج السمنة أيضا lrisin كعلامة التنبؤيه لمقارنة الأنسولين لديه

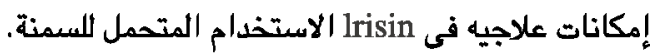
الكلمات الرئيسية: السمنة ايريسين، ممارسة الرياضة، اوبتيوبونتين. 